\title{
RESPECTING PATIENT AUTONOMY: VOLUNTARY INFORMED CONSENT IN MODERN MEDICINE
}

Grebenshchikova EG $\bowtie$, Chuchalin AG

Pirogov Russian National Research Medical University, Moscow, Russia

\begin{abstract}
The article reveals the most influential in modern bioethics approach to understanding voluntary informed consent as a way to implement the principle of respect for patient autonomy, which is determined by both legal regulation and socio-cultural factors. The authors discuss the main elements of informed consent, its specificity in clinical trials, and criteria for autonomous choice.
\end{abstract}

Keywords: informed consent, autonomy, voluntariness, principles of bioethics, clinical research

Author contribution: Research concept and design — Chuchalin AG; text writing and editing — Grebenshchikova EG

$\square$ Correspondence should be addressed: Elena G. Grebenshchikova

Ostrovityanova st. 1, Moscow, 117997; aika45@ya.ru

Received: 12.02.2021 Accepted: 25.03.2021 Published online: 30.03.2021

DOI: 10.24075/medet.2021.001

\section{УВАЖАЯ АВТОНОМИЮ ПАЦИЕНТА: ДОБРОВОЛЬНОЕ ИНФОРМИРОВАННОЕ СОГЛАСИЕ В СОВРЕМЕННОЙ МЕДИЦИНЕ}

\author{
Е. Г. Гребенщикова $\square$, А. Г. Чучалин
}

Российский национальный исследовательский медицинский университет имени Н. И. Пирогова, Москва, Россия

\begin{abstract}
В статье раскрывается наиболее влиятельный в современной биоэтике подход к пониманию добровольного информированного согласия как способа реализации принципа уважения автономии пациента, который обуславливается как нормативно-правовой регламентацией, так и социокультурными факторами. Авторы рассмотривают основные элементы информированного согласия, его специфику в клинических исследованиях и критерии
\end{abstract} автономного выбора.

Ключевые слова: информированное согласие, автономия, добровольность, принципы биоэтики, клинические исследования

Вклад авторов: концепция и дизайн исследования - Чучалин А. Г.; написание и редактирование текста — Гребенщикова Е. Г.

$凶$ Для корреспонденции: Гребенщикова Елена Георгиевна ул. Островитянова, д. 1, г. Москва, 117997; aika45@уa.ru

Статья получена: 12.02.2021 Статья принята к печати: 25.03.2021 Опубликована онлайн: 30.03.2021

DOI: $10.24075 /$ medet.2021.001

In the middle of the last century, the voluntary informed consent $(\mathrm{VIC})$ doctrine emerged against the background of both advancing medical practice and evolving clinical research [1]. The latter was connected with the Nuremberg Code, a document adopted by the international tribunal after completion of the Nuremberg Trials in August 1947, which proposed principles for conducting medical experiments on humans. The first paragraph of the Nuremberg Code reads: "the voluntary consent of the human subject is absolutely essential" [2]. The Code was not legally binding, but became the basis for international and national legislation in many countries. The need for VIC was then enshrined in the World Medical Association's Declaration of Helsinki "Ethical Principles for Medical Research Involving Human Subjects" (1964), which introduced the definition of ethical norms for "non-therapeutic research" (i.e., research pursuing purely scientific purposes) that protect the rights of legally incapacitated persons and persons dependent on the researcher. In medical practice, VIC as an established concept was reflected in numerous patient rights codes: the Patient's Bill of Rights (American Hospital Association, 1972); Lisbon Declaration on the Rights of the Patient (WMA, 1981); Declaration on Promotion of Patients' Rights in Europe (WHO European Office, 1994), etc.

In the 70s of the last century, the need for VIC was established in bioethics, which at that time was actively developing in the United States. In the same period, two main approaches to the problem were shaped in the bioethical literature, ethical-philosophical and legal. The approaches brought to the center of research thought both the legal aspects of failure of inform patients and the responsibility associated therewith, and the moral aspects of re-evaluating relationships in medicine. The doctrine of informing the patient and obtaining consent was theoretically conceptualized in the classic work by T. Beauchamp and J. Childress "Principles of Biomedical Ethics" [3], and then in the studies by other authors. According to T. Beauchamp, autonomous, independent choice and voluntariness are central to the concept of consent $[4,55]$. The independence part is realized through the person's access to the VIC process that allows this person to either authorize the plan suggested by the doctor or reject it. Beauchamp's position is shared by many researchers who argue that it is the ability to choose that fills patient's autonomy with meaning [5].

However, there are two different but interrelated aspects to the answer to the question of association between informed consent and autonomy.

First, the voluntary consent requirement of the Nuremberg Code lacks any explanation referring either to the independence or to the no harm principle ("do no harm") [6]. However, in the 1970s, National Commission for the Protection of Human Subjects of Biomedical and Behavioral Research included research ethics documents in its scope of work and changed the fundamental approach to the matter: it was clearly expressed that the purpose of consent of the research subject is to protect autonomy and personal dignity. The Commission's Belmont Report (1979) argues that "individuals should be treated as autonomous agents," and informed consent underpins respect for the individual, so that "subjects, to the degree that they are capable, be given the opportunity to choose what shall or shall not happen to them" [7]. Subsequently, this approach was established in a number of national and international documents [8]. 
Secondly, many researchers view VIC as an expression of the liberal Western tradition that advocates the importance of individual freedom and choice [9], as reflected in the ethical, philosophical and legal discourses ignited in the US in the second half of the past century. "The values underlying informed consent - autonomy and concern for human wellbeing - are deeply rooted in American culture, in our religious traditions, and in Western moral philosophy. It is not surprising that informed consent is the cornerstone of the current modern medical ethics doctrine and medical law in the United States" [10]. From this perspective, the development of the idea of VIC is viewed as part of the extended social transformations of American healthcare in the second half of the XX century, which saw consolidation of individualistic values in various social spheres. These processes affected the doctor-patient relationship: the doctor's professional authority was no longer indisputable, and the hierarchy in this relationship questioned. The transformation of paternalism was promoted by economic and structural changes that revolutionized the world of medicine, suppression of the "traditional" attitudes in the social spheres (family, church) that were previously unaffected by market values, as well as various civic movements, patient movement included. The VIC doctrine not only reflected these changes but contributed to them. Thus, the concept of patient autonomy has become firmly established in healthcare only in the last decades of the XX century.

\section{Elements of the voluntary informed consent}

The typical VIC elements distinguished in the context of discussions around bioethics are: 1) competence, 2) disclosure of information, 3) understanding, 4) voluntariness and 5) consent [11]. Through this lens, the VIC is seen as follows: a person gives informed consent to an intervention if this person is competent to act, fully informed and understands the information received, voluntarily makes the choice and agrees to the intervention. However, this approach has been criticized. For example, "competence" can be viewed as a necessary prerequisite rather than part of the process of informing and obtaining consent.

T. Beauchamp argues that VIC should be considered mainly in terms of understanding, voluntariness and consent. However, each of these elements should not be absolutized. For example, the level of understanding of the situation depends on education, age and a number of other factors. As shown in the systematic review by J. Flori and E. Emanuel, potential clinical trial participants often do not understand the information disclosed to them in the process of obtaining VIC. Moreover, there is only a few research efforts that consider the ways to improve the level of understanding [12].

At the same time, it is important to understand which choices can be considered autonomous. According to T. Beauchamp and J. Childress, the determining criteria here are as follows: 1) intention; 2) understanding 3) lack of outside influence that can affect the action [13].

\section{Intentional action}

An intentional action must be planned and consistent with the person's idea of it, although the end result may differ from the one expected. T. Beauchamp relies on the intentional action model based on the expression of will and not a desire. Intentional action includes any action and any effect that occur during plan execution. For example, a patient must decide on facial surgery that will leave a scar. The only option is to reject the intervention. Agreeing to the surgery, the patient accepts the scar as a result of the operation. The patient's consent does not mean that this patient would like to be scarred, however, it is as much a personal choice as agreeing to the operation. In many cases, a distinction can be made between intention and intentional action. Thus, "...it can be said that someone intentionally agreed to be scarred during surgery, but has no intention to receive a scar. In other words, an intentional action does not necessarily equal the intention the performer of this action has" [14].

\section{Understanding}

Understanding is the second condition for autonomous action. Understanding forms on the basis of the information necessary to comprehend the essence of the actions and consequences thereof. The latter does not mean thorough analysis of the problem but rather an apprehension of essential facts. However, in some cases, being unaware of at least one fact or misunderstanding some risk can deprive the person of adequate understanding. In addition, understanding may be limited by the person's illness, unwillingness to dialogue with the doctor or other communication problems. A person's inability to perceive information as truthful or objective, even if it is understood adequately, can jeopardize decision-making [lbid.].

\section{Voluntariness}

Voluntariness is the third prerequisite of autonomous action. A person must be free from control exercised either by external agents or by internal conditions that hinder self-government. However, not all influences may be considered controlling. T. Beauchamp focuses on the three types of influence: persuasion, coercion and manipulation. The first is about a rational effort to persuade that is not necessarily about control. By persuading a patient to get tested, the doctor most often wants to influence the behavior of but not control that patient.

Coercion involves force or threats employed to control another human being. For example, when a doctor threatens to discontinue provision of assistance if the patient does not agree to a medical intervention, the doctor seeks to control the patient. Treatment in a psychiatric hospital can be compulsory if the patient is sent there involuntarily. However, submission cannot be considered the result of coercion when someone feels a threat in the actual absence thereof. Coercion can only be acknowledged if a real and deliberate threat violates and alters a person's independent course of action. In case of coercion, even deliberate and well-informed actions can be involuntary.

Manipulation is a form of influence that forces someone to perform an action the agent of influence needs. In healthcare, the most likely forms of manipulation have to do with information. In particular, researchers addressing biomedical problems are often criticized for hiding important information and exaggerating the benefits. Often, overly attractive offers of compensation and healthcare services are also viewed as manipulative.

In this context, it is important to highlight the need to account for not only external influences but also internal factors that limit voluntariness, which can arise from, for example, a mental illness. Thus, in the future, there may arise a question about inviting an authorized person to participate in the process of obtaining informed consent, that person capable of confirming the fact that VIC was signed without external pressure and that the patient understood the essence of the medical intervention, 
and the doctor described the actions to be performed in a sufficiently informative way.

\section{Clinical trials: voluntary informed consent and patient autonomy}

As mentioned above, the Nuremberg Code played a key role in the introduction of VIC to clinical research. However, that did not mean the end of unethical research activities. For example, in 1966, Henry Beecher published an article titled "Ethics and Clinical Research" (New England Journal of Medicine), where he described 22 examples of dubious research experiments none of which had consent obtained from the subjects [15]. Realizing that the journal was read mainly by doctors, he warned the press about the upcoming publication. It ignited intense public debate and led, among other things, to the establishment of the National Commission for the Protection of Human Subjects of Biomedical and Behavioral Research, the first government agency to set bioethics policy in USA.

Another striking and well-known example of a violation of research ethics is the Tuskegee Experiment (Alabama): from 1932 to 1972, researchers studied natural course of syphilis, i.e., patients received no treatment. The study involved 399 black men, 201 of whom were controls. In 1947, there was introduced an effective penicillin-based protocol to treat the disease, but the subjects received neither treatment nor information about it. As a result, over 40 years of the experiment, 28 people died from syphilis, 100 subjects died from the associated complications, 40 wives were infected and 19 children were born with congenital syphilis. The experiment was discontinued in 1972 after a media leak. The outrage that followed led to significant changes in the field of medical research, development of the requirements for informed consent of the subjects, protection of vulnerable persons, ethical committee oversight [16], which were recorded in the Belmont report.

\section{Situations restricting autonomy in clinical trials}

Situations when a subject voluntarily signs informed consent and yet reports forced participation present a complex ethical problem in the context of current clinical trials. The reasons for such collisions are usually associated with unavailability (or limited availability) of medical resources - medicines, diagnostic and therapeutic services, - and research activities being an important source of income. Free checkup or treatment, a monetary reward or stay in the clinic are perceived as offers that cannot be refused. Accordingly, the participant says that "there is no other choice," referring to the circumstances that influence the decision. At the same time, formally, the participant makes the choice freely and voluntarily. In this case, the coercion perceived by the person making the decision is not coercion. Such morally tense situations require special attention in bioethics.

Another ethically controversial issue is the remuneration of clinical trial participants. If the amounts paid meet the expectations and the risks are comparable to everyday risks, the situation is quite clear. However, the incentives generate problems 1) as the risks increase, 2) as more appealing incentives are introduced, 3) as the economic wellbeing of the subjects deteriorates or they lose alternatives or resources [17].

The increasing risks people in difficult financial situations are exposed to can be viewed as leaving them with no other options but to agree to the appealing offers, even if in other circumstances they would have refused. In other words, how a very attractive offer is perceived greatly depends on the risks found in the background. This offer can be manipulative, but not coercive, if it does not contain a threat.

There is another aspect to the moral problem of research subject remuneration: with the over-the-top profits pharmaceutical companies gain, compensations they pay to study participants are small and unfair. The possible solution to these problems is to have the project sponsor pay fair remuneration for participation in moderate risk studies and not increase payments to attract participants to the higher risk studies [18]. Essentially, there should be an approach balancing the two extremes, underpayment and overpayment. It may seem that the simplest way to solve the problem is to completely ban a particular study, or to ban researchers from recruiting subjects from communities where difficult financial circumstances may be viewed as coercive conditions. However, taking into account that the research subjects make their choice independently and voluntarily, albeit with some restrictions, any prohibition in such situations looks morally questionable.

\section{CONCLUSION}

The theory linking VIC-related issues to patient autonomy reflects the dominant, but not the only, approach to the problem found in the scientific literature. Its heuristic potential lies not only in the ability to explicate the evolution of ethical and legal foundations - legal incidents and moral collisions - as prerequisites for reformatting relationships in clinical medicine, where adequate provision of information to the patient underpins autonomous choice, but also to draw attention to a broader sociocultural context. The latter connects transformational processes in medicine with the assertion of values of individualism and self-determination in society. Medicine has been growing more and more technological and digital lately, which intensifies these trends through expansion of the patient's awareness, fostering the desire to actively monitor health indicators with the help of health trackers and self-diagnostics devices. Therefore, it is now necessary to take into account the new contexts of the rapidly developing e-healthcare. While telemedicine entailed procedures designed to obtain VIC remotely, advances in genetics and biobanking call for rethinking of both the information component and the way in which consent is obtained for each study, as genetic data is reusable. Thus, adequate responses to the challenges posed by new biomedical technologies, as well as improvement of the doctor-patient relationship, require further interdisciplinary research addressing $\mathrm{VIC}$ theory and practice of its application in current medicine.

\section{References}

1. Dankar FK, Gergely M, Dankar SK. Informed consent in biomedical research. Computational and structural biotechnology journal. 2019; 17: 464.
2. Nuremberg Code. http://www.psychepravo.ru/law/int/nyurnbergskijkodeks.htm. Russian.

3. Beauchamp TL, Childress JF. Principles of Biomedical Ethics. 
Oxford University Press. 2001; 454 p.

4. Beauchamp TL. Autonomy and consent. In book: The ethics of consent: theory and practice. Oxford University Press, 2010; 55 p.

5. Naik AD, Dyer CB, Kunik ME, McCullough, L. B. Patient autonomy for the management of chronic conditions: A two-component reconceptualization. The American journal of Bioethics. 2009; 9 (2): 23-30

6. Beauchamp TL. Autonomy and consent. In book: The ethics of consent: theory and practice. Oxford University Press. 2010; 58-61 p.

7. The Belmont Report. Ethical principles and guidelines for the protection of human subjects of research on April 18, 1979. http://www.bioethics.ru/rus/library/id/388/. Russian.

8. Brady JV, Jonsen AR. The evolution of regulatory influences on research with human subjects. In book: Human subjects research. Springer, Boston, MA, 1982; 3-18 p.

9. Dolgin JL. The legal development of the informed consent doctrine: past and present. Cambridge Q. Healthcare Ethics. 2010; 19 (1): 97-109.

10. Berg JW. et al. Informed consent: legal theory and clinical practice.

\section{Литература}

1. Dankar FK, Gergely M, Dankar SK. Informed consent in biomedical research. Computational and structural biotechnology journal. 2019; 17: 464.

2. Нюрнбергский кодекс. http://www.psychepravo.ru/law/int/ nyurnbergskij-kodeks.htm

3. Beauchamp TL, Childress JF. Principles of Biomedical Ethics. Oxford University Press. 2001; 454 p.

4. Beauchamp TL. Autonomy and consent. In book: The ethics of consent: theory and practice. Oxford University Press, 2010; 55 p.

5. Naik AD, Dyer CB, Kunik ME, McCullough, L. B. Patient autonomy for the management of chronic conditions: A two-component reconceptualization. The American journal of Bioethics. 2009; 9 (2): 23-30

6. Beauchamp TL. Autonomy and consent. In book: The ethics of consent: theory and practice. Oxford University Press. 2010; 58-61 p.

7. Бельмонтский доклад. Этические принципы и рекомендации по защите человека при проведении исследований 18 апреля 1979 г. http://www.bioethics.ru/rus/library/id/388/

8. Brady JV, Jonsen AR. The evolution of regulatory influences on research with human subjects. In book: Human subjects research. Springer, Boston, MA, 1982; 3-18 p.

9. Dolgin JL. The legal development of the informed consent
Oxford University Press. 2001; 14 p.

11. Beauchamp TL. Autonomy and consent. In book: The ethics of consent: theory and practice. Oxford University Press, 2010; 56 p.

12. Flory J, Emanuel E. Interventions to improve research participants understanding in informed consent for research: a systematic review. Jama. 2004; 292 (13): 1593-1601.

13. Beauchamp TL, Childress JF. Principles of Biomedical Ethics. Oxford University Press, 2001; 454 p.

14. Beauchamp TL. Autonomy and consent. In book: The ethics of consent: theory and practice. Oxford University Press. 2010; 68 p.

15. Beecher HK. Ethics and clinical research. N Engl J Med. 1966; 274 (24): 1354-1360 .

16. Reverby SM. Examining Tuskegee: The infamous syphilis study and its legacy. - Univ of North Carolina Press, 2009; 384 p.

17. Faden RR, Beauchamp TL. A history and theory of informed consent. Oxford University Press. 1986; 392 p.

18. Schonfeld TL. et al. Research involving the homeless: arguments against payment-in-kind (PinK) //IRB: Ethics \& Human Research. 2003; 25 (5): 17-20.

doctrine: past and present. Cambridge Q. Healthcare Ethics. 2010; 19 (1): 97-109.

10. Berg JW. et al. Informed consent: legal theory and clinical practice. Oxford University Press. 2001; 14 p.

11. Beauchamp TL. Autonomy and consent. In book: The ethics of consent: theory and practice. Oxford University Press, 2010; 56 p.

12. Flory J., Emanuel E. Interventions to improve research participants understanding in informed consent for research: a systematic review. Jama. 2004; 292 (13): 1593-1601.

13. Beauchamp TL, Childress JF. Principles of Biomedical Ethics. Oxford University Press, 2001; $454 \mathrm{p}$

14. Beauchamp TL. Autonomy and consent. In book: The ethics of consent: theory and practice. Oxford University Press. 2010; 68 p.

15. Beecher HK. Ethics and clinical research. N Engl J Med. 1966; 274 (24): 1354-1360.

16. Reverby SM. Examining Tuskegee: The infamous syphilis study and its legacy. - Univ of North Carolina Press, 2009; 384 p.

17. Faden RR, Beauchamp TL. A history and theory of informed consent. Oxford University Press. 1986; 392 p.

18. Schonfeld TL. et al. Research involving the homeless: arguments against payment-in-kind (PinK) //IRB: Ethics \& Human Research. 2003; 25 (5): 17-20. 